\title{
FOREWORD
}

\section{PUBLISHING IN SOUTH AFRICA}

\author{
MIKE KANTEY
}

\section{Introduction}

Despite the existence of a Book Trade Association and the presence of some large conglomerates operating both inside and outside South Africa, efforts to gather sensible statistics are often met with either confusion or evasion. What follows is therefore a provisional sketch of publishing in South Africa. In a transition to a post-apartheid South Africa, my argument will be that the havoc of the past has made reconstruction essential and part of that reconstruction must involve publishing in all its aspects. Unfortunately, racial terminology remains unavoidable in the short term and I shall therefore refer to 'whites' in the conventional sense; 'blacks' as a generic term for all designated 'coloured', 'Asian' and 'black' by the state; and to 'Africans' generically for those who speak an indigenous language other than Afrikaans.

\section{A short history of publishing in South Africa}

\section{Pre-1948}

The South African press [by which we may include publishing] has been a sectional press throughout its history. Race - not language, religion or culture - has proved to be the dominant characteristic of this sectionalism, moreover, which has given the press in this country a unique status among the world's mass media of communication. (Switzer and Switzer 1978: 55)

The first 250 years of colonial rule in South Africa ensured that, from its earliest days, the Cape Colony was dependent on Europe for most of its books and other printed matter (Randall 1983: 105). In 1795, however, Johan Ritter was appointed by the Dutch colonial officials to establish a press in Cape Town on their behalf (Donker 1983: 30). Other printers for government and church soon followed. After the British occupation of 1806 and the influx of British settlers, the first signs of a free press in Dutch and English emerged. The first fully independent newspaper was the Commercial Advertiser launched by George Greig in January 1824 (Switzer and Switzer 1978: 57)

By 1842 Cape Town had nine presses, seven newspapers and six bookshops (Randall 1983: 105), while the first fully-fledged South African publishing house was started in 1854 by Jan Carel Juta (Donker, 1983: 30). Yet the majority of books continued to be imported from Europe, especially Britain, Holland and Germany, and these importations reflected the colonial view of the times. For example, in Hugh Bryan's Our Country: an elementary history of Natal (published by Thos. Nelson in 1909): '[It was] . . quite clear that the Zulus could not rule themselves or keep order in their country, so the white men were forced to do it for them ... [and] ... thousands of foolish natives were killed or put in prison' (quoted in Randall 1983: 105). 


\section{The mission presses}

As multinational and local interests established themselves for the edification of the settler communities, so the indigenous population was 'civilised' by missionaries who established their own presses for evangelisation. In 1823 the first mission press was set up in the Tyhumie valley in the Transkei, later to be known as Lovedale (Randall 1983: 105). A second press was established at Marianhill near Durban in 1887 (CCSU 1988: 28) after the 'pacification' of the Zulu kingdom.

Throughout this period and subsequently, the mission presses contributed greatly to the African language scene by publishing serious literature in African languages. Thomas Mofolo in Sesotho, Mqhayi, Jolobe, Sinxo and Jordan in Xhosa and Vilakazi and Dhlomo in Zulu all owe the first appearance of their work in print to these presses.

On the other hand it has to be recognised that one of the most important effects of these early mission presses was to reduce a rich and diverse oral tradition to a few centres of literary patronage (Peires 1980). Apart from the literary and orthographical controls which missionary editors exercised, language standards were also instituted. Thus although a host of dialects existed for each of the major African languages recognised in South Africa today, only a few came to be standardised: Xhosa around the Tyumie valley with Lovedale's Systematic Vocabulary of the Kaffrarian Language (1826); Setswana around Moffat in Kuruman in the north-western Cape (as opposed to present-day Botswana); and Sepedi around Sekhukuneland in the north-eastern Transvaal.

It was the establishment of newspapers however, rather than the printing of books, that attracted large numbers of black readers. Umshumayeli Wendaba (Publisher of the News) was started at Lovedale in 1837, Ikwezi (Morning Star) in 1844 and Isiqidimi Sama Xhosa (Xhosa Messenger) in 1876 (CCSU 1988: 27). The Editor of the last, John Tengo Jabavu, resigned to start Imvo Zabantsundu (African Opinion) in 1884, the first newspaper for a black audience to be managed by a black person, although capital was obtained from white liberals. Just as the end of the nineteenth century saw the beginnings of black resistance to white domination, so the independent black press represented a challenge to missionary and colonial presses: 'Despite ... . [a later] move from strident opposition to "anti-Native" legislation to somewhat slavish support of "liberal" white politicians and eventual control by white press groups, Imvo retains pride of place as the midwife of the alternative press tradition' (Johnson 1985: 18). ${ }^{1}$

\section{The settler presses}

By 1910 , the date of the formation of the Union of South Africa, a number of publishing houses, founded on indigenous or imported English capital, were flourishing. Apart from Juta \& Co., a major local publishing house had been founded by Thomas Maskew Miller in 1893 (Anon. 1982). In 1919, two years before the first Afrikaans primary school opened, he published the first Afrikaans readers, followed in 1923 by the first Afrikaans grammar. Two other major publishers, based in the United Kingdom, were Longmans and Oxford University Press, and in 1915 a South African branch of the latter was opened. Its purpose then, however, was solely to distribute imported books. With the defeat of the Boer republics and the establishment of Union, Afrikaner nationalism turned to countering English hegemony on the political, economic and cultural fronts. At the end of 1914 discussions were held at the house of the Stellenbosch District Bank Manager: 'Unable to raise the $£ 8,000$ required to start a newspaper, they approached [local farmer, Jannie] Marais [who had made his fortune on the diamond mines] who took up 5,000 $£ 1$ shares. Barely six months later, the first issue of Die Burger appeared' (Giliomee 1989: 115). 
These local Western Cape farming interests then continued to fuel the rise of Nasionale Pers (see below), and as Giliomee shows, the triumph of centrist Afrikaner interests.

In the meantime those presses which published for black readers had come increasingly under the control of indigenous white capital. Bantu Press (Pty) Ltd had been founded with Bantu World in April 1932 (Couzens 1979) while Jim Bailey's Drum (March 1951) focused on sex-crime-sport sensationalism and 'bridged the final gap in forging a mass, popular Black press under the aegis of White chain ownership and corporate control' (St Leger, quoted in Switzer and Switzer 1978: 57). Those who worked on Drum were apparently forbidden to participate actively in politics. On Bantu World anything 'calculated to inflame the native mind and lead to general discontent at their lot is taboo' (Smith, quoted in Switzer and Switzer 1978: 57).

\section{Post -1948}

The success of Afrikaner Nationalism at the polls in 1948 saw the beginnings of massive oppression. With the advent of the Christian National Education and Bantu Education Acts, publishing for African language speakers came to be dominated by the Department of Education and Training (DET)-controlled Prescription Committees. Two Afrikaner presses, Perskor and Nasionale Pers, flourished. A 'winning hearts and minds' approach saw a plethora of ethnic magazines emerge, especially from the State Department of Information in the 1950 s, but also from the Afrikaner groups. They also succeeded in gaining a 'virtual monopoly over the lucrative photo-story magazine market' (Switzer and Switzer 1978: 58).

Maskew Miller took advantage of its standing in the educational field, where it had a number of educational supply contracts, to publish prescribed works in African languages, as well as local editions of Shakespeare's plays and other English classics. The managing director of Longmans spoke for most multinationals at the time: 'The economic survival of South African branches of English houses depends partly on their acting as agents for the parent company in selling United Kingdom publications, and partly on the proceeds from local educational publishing' (Kerr 1959: 77). The policy at Oxford University Press of simple branch distribution of UK material had changed in 1946 when Leo Marquard was appointed 'educational manager in Cape Town empowered to publish books locally in English, Afrikaans and the Bantu languages' (Sutcliffe 1978: 267). David Philip joined OUP in 1952 and later succeeded Marquard before leaving to start his present company in 1971. During their collective stewardship some notable academic and general publishing took place, including Hobart Houghton's South African Economy and Paton's biography of J. H. Hofmeyr.

In 1983 the Longman Group took over the old Cape publishing house of Maskew Miller, but South African interest was retained through an effective 49 per cent shareholding by Hortors-Trio Rand, a daughter company of Argus Holdings. The old Longman-Penguin (SA), while being responsible for some atrocious and sycophantic educational publishing, still managed (under astute commissioning editors such as Doug van der Horst, Ian Scott and Kate McCallum) to develop far-ranging and dynamic books for the regional market. Other multinationals eager to take advantage of the proliferation of governmental bureaucracies were, for example, Heinemann, Macmillan, McGraw-Hill (later Lexican), Butterworths and Collins.

But the greatest profits from this period up to the present were made by the Nasionale Group. In 1978 they helped defeat Connie Mulder's bid for succession to B. J. Vorster (Mulder had been aided by the rival group Perskor) and today they are a major conglomerate with full affiliate companies Tafelberg, Nasou, Via Afrika, Human \& 
Rousseau, Academica and Van Schaiks with a controlling interest in Nasionale Media Bpk (including the newspapers Die Burger, Oosterlig, Die Volksblad and Beeld; the neighbourhood newspapers Metor-Burger, Tyger-Burger, Noord-Kaap, Ons Stad, Goudveld-Forum, Kroon-Nuus, PE Express and UD-Nuus; a weekly aimed at Soweto audiences, City Press; and the magazines Huisgenoot, You, Landbouweekblad, Sarie, Fair Lady, Woman's Value, Drum, True Love and Family, Finansies $\mathcal{G}$ Teqniek and Insig).

With the collapse of the Defiance Campaign and the establishment of the Republic, 'the 1960s have become known in South African history as the decade of black silence' (Johnson 1985: 20). Afrikaner and white liberal opinion blossomed in a period of economic sunshine and political drought. Independent houses such as Human \& Rousseau and Tafelberg (later to become part of Nasionale Pers) supported the emergence of the influential Sestigers. Dan Jacobson, Nadine Gordimer, Jack Cope and others found their way into print overseas. Yet the same period saw - albeit denied to most readers of the 1960 s - a rise to prominence of the Drum generation (Van Dyk 1989). Writers such as Can Themba, Todd Matshikiza and Es'kia Mphahlele chose to write in English, perhaps because of the disparagement of the vernacular tradition by the apartheid regime, but more probably because of the encouragement to Pan-Africanism given by Drum. These writers largely confirmed an earlier tradition whereby the best black writers saw their apprenticeship in journalism. But the rewards for them were mostly banning, detention and exile.

The publication in March 1970 of the Black Consciousness Movement's SASO Newsletter marked a turning point. It had a probable circulation figure of 4,000. It was followed in 1972 by Black Review, an organ of the Black Communities Programme, and Black Viewpoint, edited by Steve Biko. Clearly the grounds for the sustained opposition of the 1980 s had been laid.

In 1980, the establishment of Grassroots (circulation 25,000) in the Western Cape was followed by other community papers, notably Saamstaan (1984) and Namaqua News. Along with more conventional format newspapers, such as Weekly Mail, New Nation and South, these organs of resistance had been hammered under successive states of emergency, but have nevertheless continued.

The emergence of such alternative newspapers also saw the flourishing of magazines devoted to literature. Contrast survived throughout the 1960 s despite the original banning of its editor, Jack Cope. Notable among the more recent magazines have been New Classic, Staffrider (some early issues of which were banned - after they had sold out), Inspan and Donga (banned in 1978).

During the same period there was a gradual acceptance of African literature at the liberal white universities (Sole 1979: 16). This last was helped by the tremendous interest in Black poetry of the 1970 s. The small publishing houses which emerged in that decade David Philip in 1971, Ravan Press in 1972, Ad Donker in 1973 - gave added boost to poets such as Mongane Serote, Mafika Gwala, Sipho Sepamla and Chris van Wyk. Another important independent - Skotaville - emerged in 1982. And the advent of desktop publishing has allowed still more small independent publishers to proliferate. Most of the major publishers and many independent ones are based in Cape Town, though others are in Pretoria, Pietermaritzburg, Johannesburg, Durban or Grahamstown.

Writing in 1983, Randall's general perception of the publishing world of South Africa does not need significant alteration:

publishing in South Africa presents a fascinating picture. One can probably say it has come of age. The old dependence on the metropolitan publishers abroad has greatly lessened, except in those highly specialised areas where South Africa itself does not 
provide a sufficient market. There is a vigorous local publishing industry in English and Afrikaans. Books in the African languages are, however, still largely confined to school texts and religious material, with an occasional pastoral idyll (all safely uncontroversial). As they have acquired control over their own education systems the 'independent' homelands have opted for English as the medium of instruction, as have virtually all Black schools given the choice. This obviously poses a major challenge for the country's English-language publishers, who have to compete with the powerful, government-supporting Afrikaans publishers, who still enjoy the lion's share of the black school market. The readership explosion, particularly amongst black readers, is a major feature: ten years ago one would have scoffed at the suggestion that a literary magazine like Staffrider, catering primarily for black readers, would regularly sell 10,000 copies. (Randall, 1983: 107).

\section{Readers}

The 1985 census gives a breakdown of the South African population as follows:

\begin{tabular}{lc}
\hline & Millions \\
\hline African & 25 \\
White & 4.9 \\
Coloured & 2.9 \\
Asian & 0.9 \\
TOTAL & 33.7 \\
\hline
\end{tabular}

Of the total population 43 per cent speak an Nguni language, 24 per cent a Sotho language, 16 per cent Afrikaans, 8 per cent English and 9 per cent some other language (Wilson and Ramphele 1989: 23). Switzer and Switzer (1978: 58) give estimated figures for literacy among the African population:

$$
\begin{aligned}
& 23.8 \% \text { in } 1951 \\
& 35 \% \text { in } 1957 / 58 \\
& 49.5 \% \text { in } 1970
\end{aligned}
$$

According to the census of 1980 close on six million of the total population were functionally illiterate (cannot read, write or do simple arithmetic), of whom five million were African (Wilson and Ramphele 1989: 139). This would put literacy among African people at 80 per cent and thus show a substantial increase over the last thirty years. Yet real numbers of illiterate Africans have grown. In 1990, the International Year of Literacy, Wedepohl's comments at the Carnegie Conference of 1984 remain cautionary: 'While acknowledging the enthusiasm and achievements of many literacy groups, one must not lose sight of the sobering statistic that in 1980, out of an estimated 6 (up to 9) million illiterates in South Africa, all the ... efforts [of literacy organisations] taken together assisted no more that 25,000 persons $(0.3 \%$ of 7.5 million) to attain literacy' (quoted in Wilson and Ramphele 1989: 139).

Estimates vary as to the total book-buying market in South Africa. Working-class black readers are reported to spend only 8 percent of waking time reading (Sitas 1989). Most of 
this seems to be spent reading newspapers and magazines rather than books. Thus any attempt among established publishing houses at developing a working-class black readership for books outside the classroom has met with little success so far.

\section{Writers}

Only a few individual writers were known internationally prior to the Second World War - notably Olive Schreiner (The Story of an African Farm), Pauline Smith (The Beadle), Sir Percy Fitzpatrick (Fock of the Bushveld) and the poets William Plomer and Roy Campbell. After the Second World War, however, many more South African writers, such as Alan Paton, Nadine Gordimer, Laurens van der Post, Peter Abrahams, Jack Cope and Dan Jacobson began to make an impact overseas. Yet most published abroad, the view being that: 'if a novel in English is worth publishing at all, it is worth publishing in England for the world market' (Kerr 1959: 77).

More recently, however, some local authors have been published for a local market by local publishers - Lawrence G. Green, Herman Charles Bosman, Stuart Cloete, J. M. Coetzee, André P. Brink, Christopher Hope and Etienne le Roux. And in the last three years yet another wave of writers has appeared, including Menan du Plessis, Mike Nichol and Anthony Sher. Research carried out by the Human Sciences Research Council showed the existence of 380 writers in South Africa: 180 in Afrikaans, 120 in English and 80 in the various African languages. André P. Brink appeared to be the most popular with 37.7 per cent readers; 19 per cent preferred serious literature; 33.7 per cent leisure reading with literary merit; and 24.5 per cent trivial literature (The Argus 11 January 1988). Conversely, one of our most popular exports remains Wilbur Smith: fifty million copies of his twenty one books have sold worldwide, while the rights to his most recent book Rage were sold in London for R4.4 million (The Argus 30 September 1988). Several local literary awards provide some additional incentive. Many literary houses - Maskew Miller Longman, Daan Retief, HAUM - de Jager and Van Schaiks - have offered prizes for juvenile literature in a bid to secure indigenous prescriptions.

Yet little is done in South Africa to encourage writing per se (many prizes are for finished - and usually published - books). Few writers that I am aware of make their living from the craft, unless as journalists, teachers, copywriters, or academics. The temptation to produce work for purely commercial reasons is strong and one wonders with the late Raymond Williams how much work of stature remains unwritten for lack of sustenance. Conversely, the plastic and performing arts are well supported by state and corporate interests.

Though a thriving indigenous market now exists for writers in Afrikaans and English with a strong possibility of export and translation rights, far greater problems confront the writer of literature in African languages, since the very reception of such literature has been undermined by years of corrupt and morally bankrupt publishing for schools. Some small attempt has been made to rectify this, notably by Skotaville, but compared to the healthy situation that had enabled Thomas Mofolo and others to be published in the early part of this century, one wonders if it is not too little, too late.

Censorship has added to such problems. The plethora of laws and repressive apparatus governing publishing in South Africa have been well rehearsed before. But the rise of oral poetry in the 1970 s and of live mixed media performances, such as the Rishile poets and Mzwakhe Mbuli, is partly attributable to such restrictions:

The reasons for the use of this new form of dissemination are many. To some extent theatre and oral poetry are forms less vulnerable to censorship, due to the compression 
of language involved which allowed it to be a hiding place for meanings more accessible to the audience than the censors. Furthermore, a concern for appropriate literary techniques was given voice to. These poetry workshops and readings point to the fact that poets were now concerned to use literature as a means of direct communication rather than desiring publication as the way to circulate their work; indeed, there was a tendency among some of the younger Soweto poets during and immediately after 1976 to see all who published as suspect. This participatory and performed art emphasised the feeling in some circles connected with black consciousness that collective experience could enrich individual effort and enhance a degree of cultural unity. This emphasis on new techniques was coupled with a growing awareness of the control exercised by white liberal and overseas elements in most of the institutions and businesses connected with artistic output - publishing houses, the record industry, art galleries, and so on. Gwala, for one, expressed a dislike for the limitations of books and saw the problem of control not only one of white expertise, but also 'methods of operation that are based on white expertise'. This desire to break away from commercial enterprises aimed at exporting literature or influencing its suitability for audiences comprised of liberals and the educated black elite was at one stage discernible right from the educated and more politically articulate intellectuals involved to 'popular' entertainers and recording artists such as Mahlatini and the Mahotella Queens.

A shift towards the acceptability of publishing prose has come about more recently with the short stories of Ahmed Essop and Mtutuzeli Mtshoba (Sole 1979: 16). Vernacular literature sprang up in opposition to the 'ethnic' literature of schooling: as, for example, with the Mpumalanga Arts group in Hammanskraal in 1978. This trend has continued with the seminal Black Mamba Rising, published by the COSATU Culture and Working Life Project in 1988. Here a mixture of oral form (izibongo) and vernacular outbursts gives evidence of a revitalised tradition. Yet the act of publishing (Mzwakhe - dubbed the 'people's poet' - brought his work out on audio-tape) confirms at least the commitment to wider dissemination.

Some subtler types of censorship, however, are still practised. Obstacles are placed in the way of potential purchasers: books may be sealed in cellophane wrappers, restricted to those of voting age, or made available in university libraries only. Some other works are only available through a restricted list of bookshops.

\section{Publishing}

\section{Organisation}

There are three major professional organisations representing publishing in South Africa: the South African Publishers' Association (SAPA) comprises publishers whose primary business comes from local publishing; the Independent Book Distributors Association (IBDA), formerly called the Overseas Publishers Representatives Association; and the most junior of the three, the Associated Booksellers of South Africa (ABSA). All three subscribe to an umbrella body with its own director and secretariat, known as the Book Trade Association (BTA). In November 1989 a new organisation was formed: the Independent Publishers' Association of South Africa (IPASA). Many of the statistics used in this article were provided by the BTA.

The annual South African National Bibliography is published by the South African library. However, not all publishers submit figures for their print runs (1988: xvi). The 
statistics they give indicate that the fields in which new books are published are, in descending order of magnitude: literature, law, religion, linguistics, political science, natural science, technology, commerce, general, history and biography. But if the list is compiled on the basis of actual print runs on numbers of books published, then linguistics, literature, religion, domestic science (including cookery books), natural science, commerce, history, mathematics, political science, geography and travel is the new order. If the language of publication is considered then the order is English, followed by Afrikaans, Zulu, North Sotho (Sepedi) and Xhosa.

\section{Texts for primary and secondary schools}

According to the Book Trade Association, the total population of South Africa in 1987 was 36.16 million, of which 12.72 million were between the ages of five and nineteen years. The total schoolgoing population was 8.65 million, which can be broken down as follows:

\begin{tabular}{lcc}
\hline $\begin{array}{l}\text { Total } \\
\text { enrolment }\end{array}$ & $\begin{array}{c}\text { Millions } \\
S S A-\text { std10 }\end{array}$ & $\%$ \\
\hline African & 6.65 & 76.8 \\
White & 0.95 & 11.0 \\
Coloured & 0.81 & 9.4 \\
Asian & 0.23 & 2.7 \\
\hline
\end{tabular}

The average annual growth for African enrolment was given as between 4 and 5 per cent whereas for whites it was -2 per cent in primary schools and 2.4 per cent in secondary schools. File et al. (1989: 4) quote the per capita expenditure on whites as R2,508, while that on African children was R476. Thus for every R1 spent on an African child's education, R5 was spent on a white child's education. Using the above enrolment figures, this would mean a total expenditure on white education of nearly R2.4 billion, while expenditure on African eduction in the Department of Education and Training (DET) would have been just short of R0.9 billion.

In 1989, the DET gave as its figure for book purchases R43.8 million (Anon. 1989: 11), which would represent just under 5 per cent of its annual budget. because of their bulk purchasing arrangements, the DET wields great power, particularly as regards publications in African languages, where texts are mainly for the schools market:

Books are usually published only if they are first approved by the Department of Education and Training, who are the main purchasers of books in African languages. Another problem is that very often authors and publishers, as well as the commissioning and evaluating authority of African language books are white. The unfortunate result of this is that books reflect the white person's perception of a black child's world. (Machet 1988a: 81).

Because the sheer weight of capital is against any substantial improvement in this situation, innovation is left in the hands of small independent and socially motivated companies. So far their numbers are insignificant. With the change in the political context, however, new innovative publishing can be expected, especially from Centaur, Oxford, Heinemann and David Philip. 


\section{Academic publishing}

In 1989 some 420,000 students were enrolled at tertiary institutions, of whom 300,000 were at universities, 68,000 at technikons and 53,000 at teacher training colleges (File $e t$ al. 1989: 3). The fracturing and divisions of South African society are reflected in the character and history of the universities. The universities of Cape Town, Natal (Durban and Pietermaritzburg), Witwatersrand and Rhodes University, with a total enrolment of 47,000, are all traditional 'liberal, white and English-speaking'. However, black enrolments are beginning to exceed 10 per cent in some cases. The universities of the Orange Free State, Port Elizabeth, Pretoria, Stellenbosch, Rand Afrikaans University and Potchefstroom College for Christian Higher Education are all predominantly white and Afrikaans-speaking, with a total enrolment of 67,000. A few black students have begun to be admitted. The University of the Western Cape, at Bellville South near Cape Town had an enrolment of 12,000 . Originally disparaged as a 'bush' college set up for coloured people, the campus has declared itself a 'people's university' and has attracted arguably some of the finest minds of the younger generation of academics. The University of Durban, Westville, with an enrolment of 7,000 , was set up to serve students classified as 'Asian'. Further universities set up to serve African students, with a total enrolment of 54,000 , include the Medical University of South Africa, University of the North, University of Zululand, University of Bophuthatswana, University of Transkei, University of Venda, University of Fort Hare and Vista University (with satellite campuses scattered among various townships in the major centres). Finally, the University of South Africa, based in Pretoria, is a giant correspondence college with an enrolment of 113,000 , of whom 50 per cent are white.

Substantial local publishing for tertiary institutions takes place only for the faculties of commerce, social sciences, arts and education, since the market in medicine, engineering and the sciences is generally dominated by imports, mostly from the large American publishers. Because many of the latter have chosen to practise sanctions on exports to South Africa, sanctions busting by way of jobbers in Europe has further increased the prices of these books. In May 1989, at their conference, the African National Congress suggested that books, or at least certain kinds of books, might be exempt from the sanctions and cultural boycott campaigns. Recently, local lobbying by the BTA has succeeded in having the import surcharge lifted.

Van Schaik wrote for local publishers and academics:

In South Africa the print runs of academic textbooks are generally small because instruction is provided in both official languages of the country, which often requires two editions of a textbook; and because little standardisation of textbooks that are prescribed by the different universities takes place. Photocopying further reduces the potential market and thus indirectly causes higher prices. (Van Schaik 1989: 6)

Local academic publishing is divided: Van Schaiks (a subsidiary of Nationale Pers) has concentrated mainly on the Afrikaans campuses; Southern, Lexicon, Butterworth (under South African management since 1987) and Juta publish for politically moderate departments in all campuses; Raven, David Philip and Skotaville are favoured by the more liberal departments and campuses. Because of the high cost of imported books, some local publishers, such as Ad Donker, have been persuaded to reprint English classics that are out of print. And with the growth in regional concerns among all departments, the opportunities for local publishers and authors are now growing. These have led in turn to exports, particularly of analytical books on the South African economy and polity. 
Tertiary markets include the lucrative correspondence and business studies colleges, nursing education and technical education and these are arguably the fastest growing sections where much of the profit goes to the general trade stores.

\section{General publishing}

The weakness of the rand in relation to other currencies has undoubtedly made local publishing more viable. Machet (1988a: 94) points to a number of additional factors: joint runs in English and Afrikaans (and sometimes German and Spanish, for the tourist market) have cut the costs of 'coffee-table' books to well below the imported equivalent; local authors of some international stature are increasingly reserving rights in the local market for local publishers; apart from the captive Afrikaans market, many local publishers are making a determined effort to penetrate the African readership market.

In 1983, Gerry Struik estimated that there was a fifty-fifty split between local and overseas books. In 1984, the President of ABSA estimated the size of the local market at retail prices for both imported and local books as being R150 million (BTA 1989: 10). By 1989 , the projected growth was R225 million. The DET figure was higher, at R300 million.

For imports alone, it is clear that the UK still dominates the market. The South African Department of Trade and Industries and the Industrial Development Corporation published a table of imports of printed matter for 1988, the total value of which was R166 million (of which R6.5 million were dictionaries and encyclopaedias, R4.4 million books for the young, R1.9 million religious matter and R0.5 million poetry and plays).

Comparison with a table produced by the BTA of UK book exports for 1987 shows South Africa fourth on the list with $£ 26.6$ million, after the USA, Australia and the Netherlands. At R4 to the pound this would give South Africa an import figure of R106.4 million for UK publishers alone.

Comparison of best-seller lists compiled by two leading bookshops in Johannesburg, for fiction and non-fiction, reveal differences between local and imported successes. Taking both categories together, the top three were non-fiction titles published by local publishers. Their titles reflect the prevailing obsession on the part of white South Africans with understanding the local power elite: The Winning Way (about business techniques in top South African companies); The Last Betrayal (about the Info Scandal); and The Afrikaners: their last great trek. Taking the fiction list alone, all top ten were imports. The Weekend Argus of 16 December 1989 published a list of ten bestsellers, all in paperback. All were imported.

\section{Book market for children}

The South African National Bibliography 1988 gives the total number of titles published locally for the market for children's literature, in all languages, as 166 (1989: xvii). In 1989 , Jay Heale noted in an analysis of seventy books that a breakdown of the characteristics of these books produced the profile below. Apart from the work of the READ organisation in developing a reading culture at African schools, a new organisation called the Children's Book Forum was formed in 1987. It currently operates as a loose network in three major centres - Cape Town, Durban and Johannesburg - arranging seminars, lectures and public campaigns including an annual Readathon. 


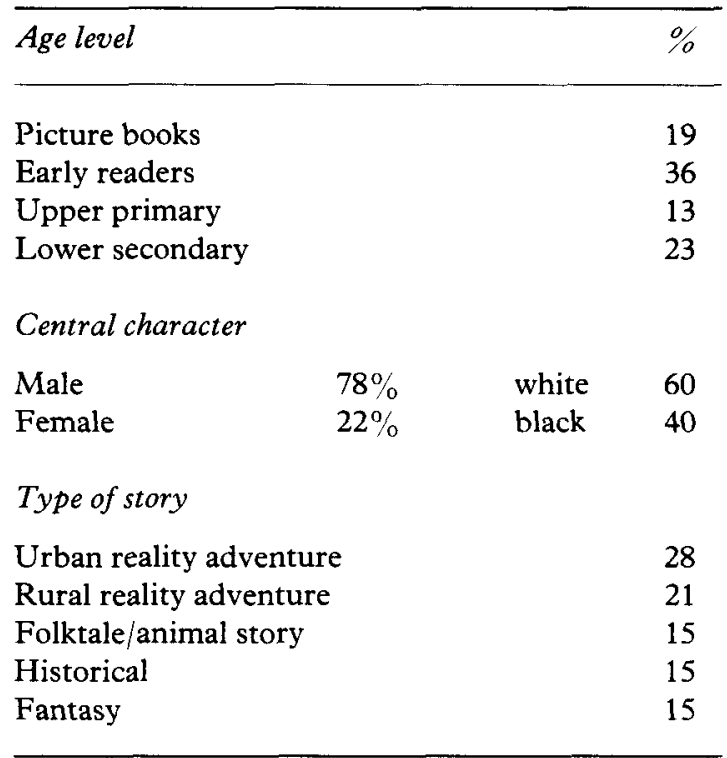

\section{Booksellers and libraries}

Although the State handles most educational trade sales, the CNA (Central News Agency) Gallo Group handles the majority of the other trade sales - estimates vary as to whether this is 60 per cent or 90 per cent of the total. The CNA was founded in 1896, dealing mainly with newspapers and magazines. By 1989 it had become a huge conglomerate with 300 retail outlets nationwide. The other major group is the Literary Group, including Exclusive Books, the Children's Bookshop, Bookworm, Campus Bookshop Literary Services, Logan's University Bookshop, Westdene Services, Book Source and Campmed; and part-ownership in Pilgrims, Young Reading, Universitas, Trans SA and United Book Distributors. Another major retail outlet is Collins (SA), who are responsible for choosing the content of gondolas at supermarkets and who supply primarily mass-market and children's fiction (Hardingham 1989). Finally, the giant reading club Leisure Hour/ Leserskring was set up with the aid of the West German giant Bertelsmann. By 1983 Leserskring was said to have 120,000 members while Leisure Hour had 15,000 and they were jointly responsible for the purchase of 500,000 books (Financial Mail 11 March 1983). By 1985, the joint membership had grown to 250,000 (Machet 1988b: 104).

Although local publishers are responsible for the selling prices of their own books, booksellers are free to decide the discount they offer to customers on imported books (Anon. 1989: 15). Discounts for institutional buyers such as libraries normally range from 33 per cent (October 1984 figures) for imported books to 10 to 15 per cent for locally produced books. Large conglomerates, however, such as CNA, Collins and Leisure Hour, can demand substantial discounts, sometimes as much as 70 per cent, though not much is passed on to the customer. Small publishers, therefore, find it difficult to gain access to the CNA chain and supermarkets.

Where local publishers are determined to capture some of the market for imported 
books, they often need to negotiate higher discounts with overseas principals in order to continue offering discounts of 33.33 per cent or more on imported books. Thus discounts of between 55 and 60 per cent are fairly common. Since the major chains of booksellers often demand very high trade discounts, some publishers such as Longmans, Penguin and Collins then rely on subsidiary companies in South Africa to negotiate terms with very nariow profit margins for large bulk supply.

A further problem, brought about by the corporate buying power of large educational departments such as the DET is that publishers are increasingly dealing directly with book buyers at head offices and bypassing booksellers. This makes the opportunities for the development of more and smaller independent booksellers unlikely and also means that the publishing of books on Third World issues, Greenpeace, alternative and so on is limited, while their markets are largely being catered for outside the large booksellers by a loose network of health shops and 'alternative' retailers.

Ad Donker (1983: 33) wrote that New Zealand had one shop for every 7,500 people while South Africa had one for every 100,000. Cape Town now has ten good bookshops serving over one million people and two major universities. In 1853 there were six bookshops (of which only Juta's remains) for a population of 23,749 - a ratio of roughly one shop to every 4,000 residents, many of whom were probably illiterate. If a book culture is to grow in South Africa, one in which the tremendous variety of culture and interest is reflected in proper bookshops throughout the land, then some kind of justice will have to be done for availability. If the independent bookshop cannot succeed, then the onus must fall on libraries and resource centres.

The Cape Provincial Library Services provides a host of fascinating statistics in their annual report (CPA 1989). With 467 affiliated libraries, 768,334 registered members borrowing $17,243,025$ books in 1988, and spending R10 million on books, they noted that despite the fall in the value of the rand and the consequent rise in price of all imported books, they had managed to buy more items with an increase of 47 per cent in their budget. Afrikaans fiction topped their list of acquisitions for 1988, followed by English fiction, non-fiction and Afrikaans juvenile fiction, reflecting the fact that the demand for Afrikaans books far exceeds that of English books. Their comments on books in African languages deserve quotation:

Acquisition of material in black languages rose by more than 300 per cent from under 6,000 in 1987 to more than 18,000 in 1988 . Although these books still lack imagination and the finer finishing touches, particularly as far as their physical appearance is concerned, it is heartening to report that we were able to find sufficient titles to purchase. (CPA 1989: 23)

Given the struggle over the question of language, and the library's expressed desire to develop more libraries among oppressed communities, it will be interesting to see how these figures change over the next decade.

The figures for readership requests (CPA 1989: $64 \mathrm{ff}$ ) indicate that Western, Southern, Karoo and North Western Cape Provincial rural areas favour Afrikaans (regardless of race); while the Eastern and South Western Cape, large towns with a strong colonial history (Kimberley, Mafikeng, Grahamstown) and cities generally favour English, with the exception of specific urban communities. Matched with an overlay of voting (or nonvoting) patterns of the last general elections, one can suggest that nearly 200 years after the Anglo-Boer War, the divisions around language and culture remain fairly entrenched in rural areas but are starting to break down in the urban areas. 


\section{Print production}

As mentioned earlier, the advent of desktop publishing has enabled certain independent publishers to develop within the confines of the establishment industry. Nevertheless the huge cost of paper, the monopolistic practices in the bookselling industry and high capital costs of even the cheapest computer prevent the majority of people from contributing to the dissemination of information and culture. If we are convinced that books are durable, relatively cheap to produce, and have contributed to a tremendous growth in human knowledge over the last 500 years, then it seems axiomatic that access not only to the product itself but to the means of its production should be encouraged. ${ }^{3}$ Apart from the tendency for local producers to keep their prices on a par with imported paper, the enormous costs of paper are partly attributable to the present sanctions of the Scandinavian countries against South Africa. As these countries are sympathetic to the struggle it seems ludicrous that it is their sanctions which are denying the possibilities of printing. A way round could be for them to establish an independent paper mill to serve the SADCC countries but Human (1989) estimates the cost as approximately R1.5 billion, making this an unrealistic solution. Perhaps small-scale paper and rag recycling plants would be more practical.

\section{Marketing and distribution}

As with most other industrialised nations, publishers bring out regular catalogues and prospectuses. Representatives then visit schools, libraries, booksellers and education departments for the bulk of the sales. In addition to Leisure Hour/Leserskring, many publishers are making increasing use of direct mail, with or without the consent of booksellers. Most co-operation with booksellers takes place through the medium of paid advertising and, in the case of Struik, CNA, Tafelberg-Human \& Rousseau and Leisure Hour/Leserskring, through rights and deals before printing takes place.

Marketing and distribution could be described as being among the biggest challenges facing alternative publishers in the International Year of Literacy. In 1980 a number of agencies formed the Joint Distribution Group whose major objective was to distribute alternative publications to various communities, students and workers. After a decade of short-lived triumphs, repression and vacillation, it seems that its concerns are finally becoming the concerns of the very organisations, communities and trade unions they were hoping to serve. COSATU and the United Democratic Front called for a Media Summit in 1990 which was somewhat delayed by the announcements of 2 February. The formation of IPASA also bodes well for a redistribution of publishing interests. The change in state thinking, however, has thrown the entire question of publishing into a new light. If, as is everywhere alleged, the corridors of power will soon be ringing with the sound of fresh boots, then the entire nature of academic research, educational planning and cultural practice will be experiencing a profound shift in emphasis. With any luck, this will in turn lead to the need for an entirely different article by the year 1995.

Mike Kantey

David Philip Publishers

\section{Notes}

1 For a fuller account of this period and the later development of an alternative press, 
see also Couzens 1979, WACC 1985, CCSU 1988 and Switzer and Switzer 1978.

2 SSA stands for sub-standard A, the first year of schooling, while std 10 stands for standard 10 , the last year of schooling.

3 The South African government recently announced an investigation into restrictive practices in the paper industry (Business Day, 16 February 1990). Nampak MD Don McCartan said that while exessive demand worldwide for paper had pushed prices up, there had been a tendency for local producers Sappi and Mondi (who enjoy little effective competition) to price at parity. Interpak group MD Tony Rudston suggested that increases had exceeded both the consumer price index and the inflation rate.

\section{Acknowledgements}

I am grateful to the many people who helped me gather the information required for this article. Particular thanks are due to librarians Penny Bristow of Giyani College, Mary Nassimbeni of UCT and Jenny Heyerdahl of South Africa Library; to publishers Andrew Meyer of Century-Hutchinson, Annari van der Merwe of Tafelberg and James Clarke of Oxford University Press; and finally to Keyan Tomaselli of the Centre for Contemporary Cultural Studies, University of Natal, Durban and Jay Heale, children's book specialist.

\section{References}

Abrahams, Lionel, 1986. 'Lionel Abraham's view of publishing in Johannesburg', in Friends of the University of Witwatersrand and Library Newsletter, 27 December. Anon., c. 1982. 'The Maskew Miller Story', Cape Town: Maskew Miller (roneo). Anon., 1989. Publishing: an overview, Cape Town: Book Trade Association (BTA). Beresford, Belinda, 1989. 'Publishing: last refuge of the hardy individualist', in The Weekly Mail Review/Books, supplement to The Weekly Mail, 25-31 August, Cape Provincial Association (CPA), 1989. Report of the Director, Library Service, 1988, Cape Town: Cape Provincial Library Service.

CNA Gallo Ltd, 1989. Annual Report 1989. Johannesburg.

The Contemporary Cultural Studies Unit (CCSU), 1988. 'Community and the progressive press: a case study in finding our way', fournal of Communication Enquiry, 12(1): $26-44$.

Couzens, Tim, 1979. 'A short history of "World" (and other Black SA newspapers)', Inspan, 1(1): 69-93.

Department of Trade and Industries/Industrial Development Corporation, 1989. Making it in the $R S A$, Pretoria.

Donker, Ad, 1983. 'English language publishing in Africa', English in Africa, 10(1): 29-35.

File, Jon et al., 1989. 'Towards the day of hard choices', UCT Nerws Magazine, 16(2):3-7.

Giliomee, Hermann, 1989. 'Afrikaner capital and Afrikaner nationalism' in James Wilmot and Mary Simons (eds.), The Angry Divide, Cape Town: David Philip, pp. 63-79.

Hardingham, Paul, 1989. Personal communication, 11 November.

Heale, Jay, 1989. Personal communication, 2 December.

Human, Koos, 1989. Speech at South African Bibliophiles Conference, 22 November.

Johnson, Shaun, 1985. 'Barometers of the liberation movement: a history of South Africa's alternative press', Media Development, special issue on Alternative Communication in South Africa: 18-20.

Johnson, Stephen, 1989. Personal communication, 16 November. 
Kerr, W.P., 1959. 'The British publisher in Southern Africa', South African Libraries 26(3): 73-9.

Machet, Myrna, 1988a. 'Authorship and book publication in South Africa' in Shillinglaw and Thomas, 1988, pp. 77-100.

— 1988b. 'Bookselling and distribution of periodicals and non-book media' in Shillinglaw and Thomas 1988, pp. 101-12.

Markstein, Marthie (ed.), 1983. The Galley, Cape Town: Maskew Miller Longman (inhouse journal).

Meyer, Andrew, 1989. Personal communication, 3 November.

Moss, Glen, 1989. Speech at UCT (University of Cape Town) Summer School, Cape Town, 18 January.

Patel, Leila, 1985. 'How small media can organise communities', Media Development, special issue on Alternative Communication in South Africa: 12-14.

Peires, Jeffrey, 1980. 'Lovedale Press: literature for the Bantu revisited', English in Africa, $7(1): 71-85$.

Perold, Helene, 1989. Speech to UCT (University of Cape Town) Summer School, Cape Town, 19 January.

Randall, Peter, 1975. "Minority" publishing in South Africa', African Book Publishing Record, 1: 219-22.

-1983. 'Publishing in South Africa: challenges and constraints', The African Book Publishing Record, 9(2-3): 105-8.

READ Organisation, 1989. READ Annual Report 1989. Johannesburg.

St Leger. F. V., 1974. 'The African Press in South Africa' unpublished PhD thesis, Grahamstown: Rhodes University.

Shillinglaw, Noel and Thomas, Wanda (eds.), 1988. The Information Society, Johannesburg: Ad Donker.

Sitas, Ari, 1989. Speech at UCT (University of Cape Town) Summer School, 18 January.

Sole, Kelwyn, 1979. "The abortion of the intellect: literary criticism and "change" in South Africa today', Work in Progress, 5: 13-28.

Sutcliffe, Peter, 1978. The Oxford University Press: an informal history, Oxford: Oxford University Press.

Switzer, D. and Switzer, L., 1978. 'South African libraries and the Black Press', South African Libraries, 46(2): 55-8.

Van Dyk, Bruno, 1989. 'Short story writing in Drum: an overview', HSRC Bulletin, 1(17): 4-5.

Wilson, Francis and Ramphele, Mamphela, 1989. Uprooting Poverty, Cape Town: David Philip.

World Association for Christian Communication (WACC), 1985. Media Development, special issue on Alternative Communication in South Africa, London, March. 